\title{
耳鼻咽喉科領域における手術部位感染防止を 目的とした周術期抗菌薬投与法の再考
}

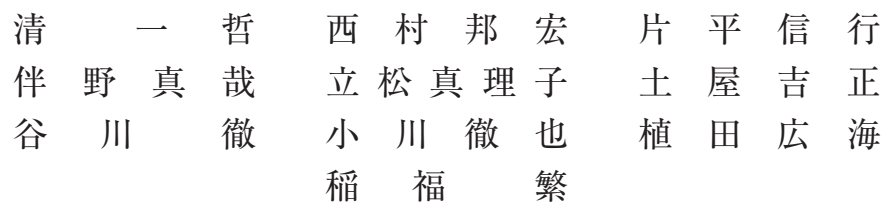

要旨：周術期予防的抗菌薬投与方法について耳鼻咽喉科領域では未だ EBM に基づいた詳細な考察がな されていない。当院では 2003 年より SSI（術後創部感染）防止サーベイランスを随時行っているが, 今回は投与期間を短縮した新たな試みを報告する。対象は当院手術室で手術を受けた 298 名, 例外症例 を除き術当日で抗菌薬投与を終了しSSI 発生の差を比較した。結果, 全体の SSI 発生率は $1.7 \%$, 術当 日のみの抗菌薬使用群では $1.2 \%$ あった。研究当初より比較するとSSI 発生率は徐々に改善を認めて おり, この為耳鼻咽喉科領域での予防的抗菌薬使用量は大多数の症例が手術日当日のみの使用で十分で あることが考えられた。

キーワード : 術後創部感染 (SSI), 予防的抗菌薬投与 (AMP), 術後創傷処置, 污染度分類

Summary Reconsideration of administering antimicrobial prophylaxis agent to aim at surgical site infection prevention in the field of otorhinolaryngology:

Kazuaki Sei, Kunihiro Nishimura, Nobuyuki Katahira, Shinya Banno, Mariko Tatematsu, Yoshimasa Tsuchiya, Tohru Tanigawa, Tetsuya Ogawa, Hiromi Ueda and Shigeru Inafuku. Department of Otorhinolarygology Aichi Medical University

There has still been no detailed consideration of the mode of administering antimicrobial prophylaxis based on EBM when operating in the field of otorhinolaryngology. We have undertaken surgical site infection (SSI) prevention surveillance in our hospital as necessary since 2003, and report here our recent attempt to shorten the administration time. We compare the difference in SSI outbreak in 298 patients operated on in our hospital (excluding exceptional cases) whose antimicrobial agent treatment had ended. As a result, the overall SSI outbreak rate was $1.7 \%$, and the rate was only $1.2 \%$ on the day of operation in the antimicrobial agent administration group. The SSI incidence gradually improved compared to the time at which the study began. Thus, antimicrobial prophylaxis in the field of otorhinolaryngology is considered to be effective only on the day of operation (AMP) for many patients.

Key words: surgical site infection (SSI), antimicrobial prophylaxis (AMP), post-operative treatment, classification of degree of contamination 


\section{はじめに}

手術患者の予定外な入院期間延長は, 患者の治 療に対する不信感や医療コストの増大等, 患者, 医師，病院側それぞれについて各種負担となって いる。その予定外の因子として術後感染症が最多 であることは疑いの余地が無い。当施設では 2002 年より手術目的で入院してきた患者に対し て CDC (Centers for Disease Control and Prevention：アメリカ疾病予防センター）の各種ガ イドライン ${ }^{1)}$ を参考にして, 術後創部感染（Surgical Site Infection：以下 SSI）の発生率減少を 目標に調査, 検討してきている。各種要因の中で も周術期の予防的抗菌薬投与法の再考は現場 タッフの負担減, 耐性菌の出現抑制はもちろんの こと DPC（診断群別支払方式）の点から考えて も医療費削減につながり, 入院期間短縮による患 者の負担減にもなる。今回我々は適応症例につき 術当日のみの抗菌薬投与での研究を行ない, その 上で過去当施設が報告してきた結果 ${ }^{2-4)}$ 及び他科 外科領域の結果と比較検討した。

\section{対 象}

2008 年 1 月 7 日から 2008 年 8 月 31 日までの 期間に愛知医科大学耳鼻咽喉科で手術適応と診断 され，入院して全身麻酔もしくは局所麻酔手術を 行った患者 298 名（男子 187 人，女子 111 人）を 対象とした。術前の手術創は 4 段階に class 分類 されるのが一般的であるが，耳鼻咽喉科領域でス タンダードな class 分類は存在しない為 CDCの
ガイドラインや新川の分類 ${ }^{5)}$ を参考にして表 1 のような当科独自の分類を使用している。

\section{方法}

前研究 ${ }^{2,3)}$ より当施設での周術期抗菌薬は今ま で術後 2 日間投与を基本としてきたが，今回より 術当日のみへと変更した。選択した薬剤は前回報 告 ${ }^{2)}$ にて有意差の無い CEZ (セファゾリン), と PIPC（ピペラシリン）を選択，小児についても 同薬剤を体重換算で計算し使用した。

投与方法は執刀 30 分前に抗菌薬を経静脈投与 開始し, 執刀前には 1 回目の抗菌薬が終了するよ うに調節した。手術終了し帰室後同種, 同量の抗 菌薬を再度 1 回投与し, その後抗菌薬は使用しな いよう努めた。手術時間が 3 時間を越えるとき や，術中輸血を行った症例に対してはその都度術 中執刀前と同量の抗菌薬を投与した。入院直後よ り経時的に当科で作製したオリジナルのサーベイ ランスシート に2)患者情報と創部，全身状態を記 載し, SSI を含め術後患者の身体に感染症状，所 見が検出されたら可能な限り感染部位を特定して 細菌検查を行い, 感染部の処置を含めて治療的抗 菌薬を投与した。

統計は $\chi^{2}$ 検定を用いた。

SSI 防止目的の予防的抗菌薬は class I と class II が対象とされており class III， IV は術前より最 適かつ十分な治療目的の抗菌薬が必要となる為, 当日のみの抗菌薬投与群からは除外される。ま た，以下の症例は class I， II に当てはまるが諸 理由により例外としている。

表 1 class 分類

· class I (clean : 清潔創)

腺組織・頸部良性腫揚摘出術，アブミ骨手術，顔面神経減荷術，など

· class II (clean-contaminated : 準污染創)

鼓室形成術，鼓膜形成術，鼻茸切除術，鼻中隔矯正術等明らかな膿汁貯留の無い鼻手術，

扁桃摘出術，喉頭微細手術，頸部郭清術を含む悪性腫癔手術，気管切開術，など

- class III (contaminated : 污染創)

明らかに膿汁の流出, 貯留を認める耳手術, 鼻副鼻腔手術, 先天性耳瘦管摘出術

細菌検查で局所炎症の原因菌が検出されている手術症例, など

· class IV (dirty or infected : 不潔・感染創)

深頸部膿瘍排膿手術，肺炎を合併している気管切開術，など 
表 2 SSI 判断症例

\begin{tabular}{|c|c|c|c|c|c|c|}
\hline 年齢 & 性別 & 手術名 & class & 発生日 & 判断所見 & 対処法, 細菌検査, 補足 \\
\hline 68 歳 & $\mathrm{F}$ & 耳下腺腫瘍摘出術 & I & 7 日目 & $\begin{array}{l}\text { 縫合不全 } \\
\text { 浸出液 }\end{array}$ & $\begin{array}{l}\text { 抗菌薬＋創部処置 } \\
\text { 細菌検査 non }\end{array}$ \\
\hline 2 歳 & M & $\begin{array}{l}\text { 口蓋扁桃摘出術 } \\
\text { アデノイド切除術 }\end{array}$ & II & 3 日目 & $\begin{array}{l}\text { 創部污染 } \\
\text { 口臭, 発熱 }\end{array}$ & 抗菌薬投与 \\
\hline 80 歳 & $\mathrm{F}$ & 舌部分切除 & II & 5 日目 & $\begin{array}{l}\text { necrosis } \\
\text { 創部離解 }\end{array}$ & $\begin{array}{l}\text { 抗菌薬 + 口腔清拭（絶食） } \\
\text { 放射線 50Gy 後 }\end{array}$ \\
\hline 43 歳 & M & $\begin{array}{l}\text { 鼻中隔矯正術 } \\
\text { 下鼻甲介切除術 }\end{array}$ & II & 5 日目 & 膿性鼻汁 & $\begin{array}{l}\text { 抗菌薬 + 頻回鼻処置 } \\
\text { Enterobactor cloacae + + }\end{array}$ \\
\hline 32 歳 & $\mathrm{F}$ & 先天性耳㾇管摘出術 & III & 2 日目 & 発赤, 腫脹 & $\begin{array}{l}\text { 抗菌薬 + 創部開放, 圧迫 } \\
\text { 術前から㿉孔より膿栓排出 }\end{array}$ \\
\hline 50 歳 & M & $\begin{array}{l}\text { 内視鏡下副鼻腔手術 } \\
\text { 鼻中隔矯正術 }\end{array}$ & III & 4 日目 & 膿性鼻汁 & $\begin{array}{l}\text { 抗菌薬 + 頻回鼻処置 } \\
\text { 手術中菌検 MRCNS + + } \\
\text { 術後菌検 non }\end{array}$ \\
\hline
\end{tabular}

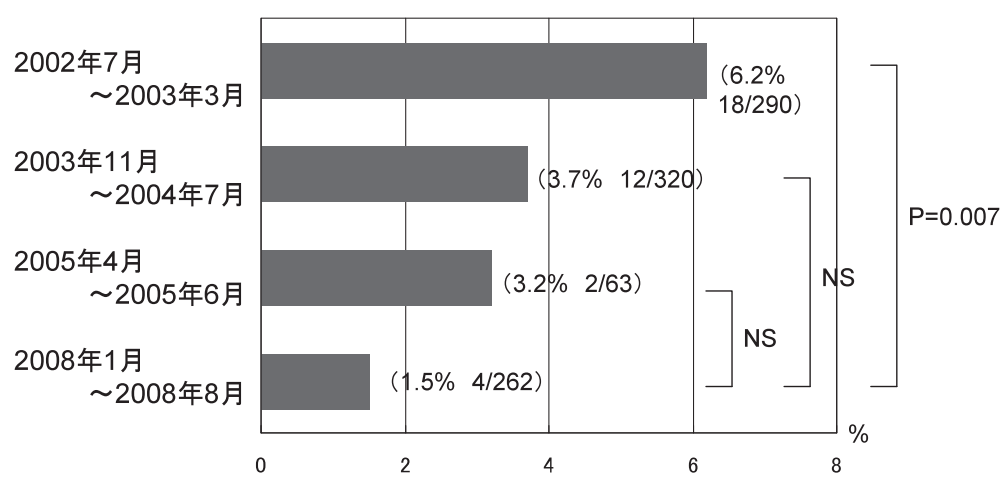

図 1 class II 以下 SSI 発生率

・悪性腫瘍に対する長時間手術で遊離皮弁，血 管吻合を行った症例や人工内耳手術等人工物を埋 め込んだ症例等, 術後感染が重篤な事態を引き起 こすもの，生命の危機に直結する症例。

- 副鼻腔手術後, open 法による中耳手術後等正 常な防御機構を失った部位にガーゼ, 止血スポンジ 等を留置した場合は抗菌薬を術後 2 日間投与する。 尚, 副鼻腔炎手術後の維持療法であるマクロライ ド長期半量投与療法はSSI 予防や治療的抗菌薬と は目的が異なるので術後無投与群として評価する。

\section{結果}

全 298 例中 SSI と判断したものは 6 例 $(2.0 \%)$ であった（表 2)。class II 以下 262 例の中では 4 例 $(1.5 \%)$, 手術当日で抗菌薬を終了した群 171
例中では 1 例 $(1.2 \%)$ のみ SSI と診断された。 一般に術後感染症の判断基準として用いる SIRS の判定基準には 1 例もあてはまらなかった。ま た, 過去当施設で行った研究 ${ }^{2-4)}$ との SSI 発症率 について比較検討したところ class II 以下群 SSI 発生率で第 1 報と第 4 報との間には有意差が得ら れた（図 1，2）。またSSI と判定した症例中，耐 性菌が検出された症例を表 3 に示す。今回は研究 開始後初めて耐性菌が検出されなかった。

\section{考察}

1. 術当日のみの抗菌薬使用

日本に扮いて, 周術期抗菌薬はつい 10 年程前 までは大多数の施設で術後 1 週間前後漫然と投与 されていたように思われる, しかし医療費コスト 


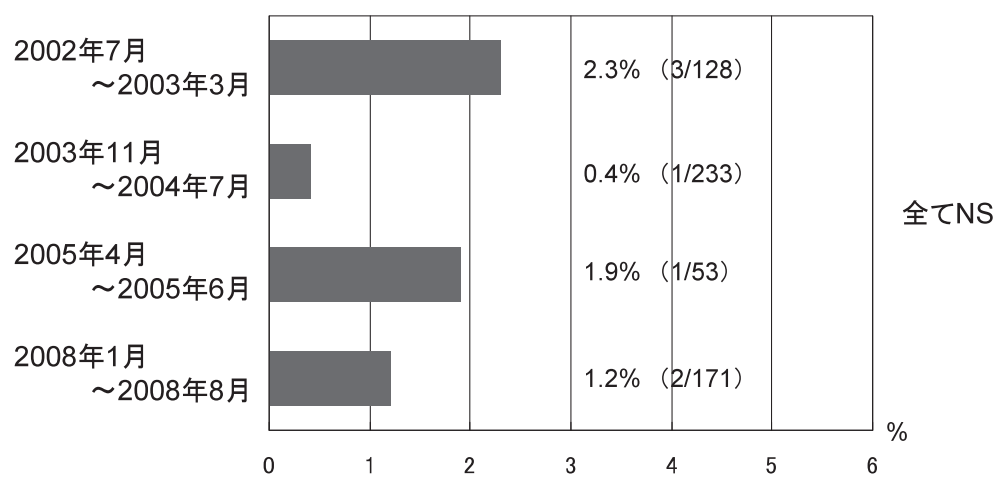

図 2 抗菌薬投与術後 2 日以内 SSI 発生率

※今回の值は術当日のみ

表 3 過去術後耐性菌が検出された症例

\begin{tabular}{|c|c|c|c|c|}
\hline & 期間 & 手術 & class & 検出菌 \\
\hline 第 1 報 & $2002 / 7 \sim 2003 / 3$ & $\begin{array}{l}\text { アブミ骨手術 } \\
\text { 鼓室形成術 }\end{array}$ & $\begin{array}{l}\text { I } \\
\text { II }\end{array}$ & $\begin{array}{l}\text { MRSA } \\
\text { MRSA }\end{array}$ \\
\hline 第 2 報 & $2003 / 11 \sim 2004 / 7$ & $\begin{array}{l}\text { 側頸囊胞摘出術 } \\
\text { 内視鏡下副鼻腔手術 } \\
\text { 鼓室形成術 } \\
\text { 鼓室形成術 }\end{array}$ & $\begin{array}{l}\text { I } \\
\text { II } \\
\text { II } \\
\text { II }\end{array}$ & $\begin{array}{l}\text { MRSA } \\
\text { PRSP } \\
\text { Pseudmonas.aeruginosa } \\
\text { Pseudmonas.aeruginosa }\end{array}$ \\
\hline 第 3 報 & $2005 / 4 \sim 2005 / 6$ & $\begin{array}{l}\text { 鼓窒形成術 } \\
\text { 内視鏡下副鼻胿手術 }\end{array}$ & $\begin{array}{l}\text { II } \\
\text { III }\end{array}$ & $\begin{array}{l}\text { MRSA } \\
\text { MRCNS }\end{array}$ \\
\hline 第 4 報 & $2008 / 1 \sim 2008 / 8$ & 耐性菌の検出は見られず & & \\
\hline
\end{tabular}

の問題や多剂耐性菌の発生等が指摘されるように なり日本化学療法学会では術後抗菌薬の適正使用 が推奨されるようになった ${ }^{6)}$ 。現在一般外科では 多施設が参加の上 SSI 発生減少に向けて調査, 研 究が行われているが7), 耳鼻咽喉科領域では我々 の狩猟し得た中では単施設の発表のみで症例数も 少なく, この分野に関しては一歩遅れている感じ は否めない。当施設では術後 SSI 発症率の低下を 目標に 2002 年より周術期の創部, 全身管理を再考 してきている。その中でも主要な項目に抗菌薬の 適正使用を掲げその都度報告してきているが2-4), 今回は前回報告した術後 3 日間投与から手術当 日のみに短縮してもSSI 発生率に大きな差は見ら れなかった（図 2)。これは開腹手術等一般外科 の class II の手術と比較してもかなり低い值で, class I であるへルニア手術や開胸手術に近い発 生率となっている7)。また一般外科での class II
手術では, 抗菌薬を第 1 もしは第 2 世代のセ フェム系薬 4 日以内投与を推奨しており ${ }^{8)}$ ，それ でも尚 10 ～20\%程度の SSI 発症率という結果を ふまえると, 頭頸部外科手術の特徴として侵襲領 域も狭く, 時間も短時間の手術が多いため, 執刀 前に投与抗菌薬の血中濃度を十分に上げておけば 術当日のみの投与でSSI 発生を抑制できると考え られた。ただ我々の報告は過去のものを併せても 1000 例をわずかに超えるのみで, 他科の報告に 比べても圧倒的に母数が少ない。今後も症例数を 増やしていくことは必要であり, その過程で新た な問題, 結論が得られる可能性はあると思われる。

2. 耐性菌

菌交代現象は単一抗菌薬投与 4 日目頃より起こ るといわれており ${ }^{8)}$, 以前は当施設でも MRSA 等, 多剂耐性菌に苦慮させられた症例も何例か存 在した。表 3 のように過去 3 回の研究では MRSA 
表 4 当研究の時系列

\begin{tabular}{|c|c|c|c|}
\hline & 期間 & 症例数 & 抗菌薬使用法についての履歴 \\
\hline \multicolumn{2}{|c|}{ 研究前より施行 } & & ※閉創時洗浄, 止血の徹底 \\
\hline \multirow[t]{3}{*}{ 第 1 報 } & 2002 年 7 月 & & \\
\hline & ～ 2003 年 3 月 & 290 例 & 術後抗菌薬投与日数 7 日間と 3 日間との比較 \\
\hline & & & $\begin{array}{l}\text { ※術前の除毛, 剃毛廃止 } \\
\text { ※創部消毒の廃止, 創傷保護材の使用 } \\
\text { ※術前までの感染コントロール }\end{array}$ \\
\hline \multirow[t]{3}{*}{ 第 2 報 } & 2003 年 11 月 & & \\
\hline & ～ 2004 年 7 月 & 345 例 & $\begin{array}{l}\text { 抗菌薬の種類（CEZ, PIPC）での SSI 発生の比較 } \\
\text { 全例術後 } 3 \text { 日間投与 }\end{array}$ \\
\hline & & & $\begin{array}{l}\text { ※開放式ドレーンの廃止 } \\
\text { ※術後の血糖コントロール }\end{array}$ \\
\hline \multirow[t]{3}{*}{ 第 3 報 } & 2005 年 4 月 & & \\
\hline & ～ 2005 年 6 月 & 72 例 & $\begin{array}{l}\text { 術後抗菌薬を経静脈投与と経口投与との比較 } \\
\text { 全例術後 } 3 \text { 日間投与 }\end{array}$ \\
\hline & & & ※創縫合時の縫合糸の選択 \\
\hline 第 4 報 & $\begin{array}{l}2008 \text { 年 } 1 \text { 月 } \\
\text { ～} 2008 \text { 年 } 8 \text { 月 }\end{array}$ & 298 例 & 術当日のみの抗菌薬投与での過去との比較 \\
\hline
\end{tabular}

※その他の因子登用時期

を含め耐性菌が検出された SSI がみられたが, 抗 菌薬の短期終了だけでなく一処置一手洗いや処置 時ディスポーザブルグローブの使用等, 院内感染 対策の理念を浸透させる事により, 今回の研究で は初めて術後耐性菌は検出されなかった。引き続 き発生予防に尽力して行きたいと考えている。

3. class II 以下 SSI 発生率

class II 以下の発生率は図 1 のように回を重ね るごとに低下してきている。これはもちろん周術 期抗菌薬投与法の改良だけではなく, 術創部の対 処法, 入院中の全身管理等 SSI 発生予防に対して 種々の因子を順次登用, 改善, 廃止していった結 果と考える。以下の項目は抗菌薬投与法以外で SSI 発生率低下目的にて採用, 変更していったも のであるが，これらは CDCのガイドラインにお いて感染制御部の専門家がSSI 防止に対して効果 的であると判断し, 全ての施設に適応, 採用され るべきと推奨されたもので, その中でも強く実行 することを勧められているカテゴリー I A 及び I B に格付けされた項目である。表 4 には抗菌薬 に関するものも含め, 2002 年以降順次変更して
いった項目を時系列に示してある。

・創部消毒の廃止, 創傷保護材の使用

手術後縫合部位は基本的にフィルムドレッシン グにて湿潤療法行い抜系時まで創部は外気に触れ させない。保護材の張り替えや, 創部消毒も行わ ない。

・創縫合時の縫合糸の選択

筋層縫合や皮下縫合時は吸収糸を用いる。編ん でいないモノナイロン糸が好ましい。皮膚縫合も 含めて最低限の縫合数で閉創する。

·閉創時洗浄, 止血の徹底

死腔部の凝血塊は感染の温床となり得る。閉創 前に確実に止血作業を行い, 残っている凝血塊は すべて洗浄する。死腔ができそうな場合は圧迫も しくは陰圧をかける。

・開放式ドレーンの廃止

開放式ドレーンは逆行性感染を起こしやすいの で, 排液や陰圧目的でドレーンを留置するときは 閉鎖式ドレーンを用いる ${ }^{9)}$ 。

・術前の除毛, 苟毛廃止

耳手術や耳下腺手術等以前は前日に剃毛を行っ 
ていた。しかし前日の剃毛，除毛は皮膚に微小な 損傷を引き起こし，SSI 発生の要因となる。現在 当施設では上記疾患には苟毛は行っておらず，中 耳癌に対する側頭骨手術等どうしても必要な事例 のみ手術室で執刀直前に行っている ${ }^{10)}$ 。

・術前までの感染コントロール

SSI は class III 以上になると明確に発生率が 上昇する ${ }^{3)}$ 。 class III や IV の症例はいかに術前に class II 以下に移行できるかが重要になってくる。 緊急でなければ炎症が落ち着くまで手術は延期す ベきであるし，手術日が決まっているのであれば 術前より感染部位に対する治療的な抗菌薬投与, 処置を行うべきである。

・術後の血糖コントロール

高血糖は創部の治癒速度を遅延させ, 易感染性 の状況を作り出す。糖尿病と診断されている患者 の血糖コントロールはもちろん, 既往にない患者 でも手術によるストレスより耐糖能異常を起こす ことがあるので, 術後一度は早朝血糖測定を行う ベきである。

以上，主なものを列記したが，何よりも重要な ことは臨床に携わる医師誰もが正確に創部の状態 を把握でき，異変時に正しく対処できるような教 育を受け，実践できることであるかと思われる。 耳鼻咽喉科は基本的には外科であることを念頭に 置き，手術自体の精度をあげると共に周術期の患 者管理に対しても最適な処置ができることが理想 であると考える。

\section{結 語}

・耳鼻咽喉科領域における class I, II に対す る予防的抗菌薬は, 手術当日のみの使用でSSI 発
生を予防することができる。

- 周術期の抗菌薬, 術後創部管理, 危険因子の 排除等を見直し，医師の創部処置に対する意識を 変換，啓蒙することにより SSI 発生率は暫時数值 として低下してきており，一連の研究については 有意義な結果を得られたと考えている。

\section{文献}

1) Mangram AJ, Horan TC, Pearson ML, et al: Guidline for prevention of surgical site infection. Infect Control Hosp Epidemiol $20: 250-269,1999$.

2）清一哲, 上村隆雄, 坂野立幸, 他: 耳鼻咽喉科 領域における術前・術後管理一SSI に基づいた術後 抗生剂使用法の実践一。耳鼻臨床，(補） $113: 93$, 2003.

3）清一哲, 坂野立幸, 吳 孟達, 他: 耳鼻咽喉科 領域における手術部位感染防止のための予防的抗 菌薬投与法.耳鼻臨床，99：697-704，2006.

4）清一哲, 坂野立幸, 吳 孟達, 他: 耳鼻咽喉科 領域に扮ける手術部位感染防止のための経口予防 的抗菌薬投与方法. 日耳鼻感染症研究会, 25： 183-188, 2007 .

5）新川敦, 田村嘉之, 高橋秀明, 他：耳鼻咽喉科 領域の周術期に扔ける感染症対策一手術の污染度 分類一. 耳鼻咽喉科感染症研究会, $16: 135-140$, 1998.

6）竹末芳生, 三鴨広繁, 荒川創一, 他 : 術後感染予 防抗菌薬臨床試験ガイドライン。 日本化学療法学 会雑誌， $55 ： 296-303 ， 2007$.

7）針原康, 小西敏郎：手術部位の定義とサーベイ ランスの実際。化学療法の領域, 24:20-27，2008.

8) 日本感染症学会・日本化学療法学会編集：抗菌薬 使用のガイドライン, 50-59, 協和企画, 東京, 2008.

9) Sarr MG, Parikh KJ, Minken SL, et al: Closed-suction versus Penrose drainage after cholecystectomy. A prospective, randomized evaluation. Am J Surg $153:$ 394-398, 1987.

10) Alexander JW, Fisher JF, Boyajian M, et al: The influence of hair-removal methods on wound infections. Arch Surg $118:$ 347-352, 1983. 